\title{
Financial Analysis of Water Management Practices in Cranberry Production in Quebec, Canada
}

\author{
Ana-Maria Bogdan ${ }^{1}$, Suren Kulshreshtha ${ }^{2} \&$ Jean $_{\text {Caron }}{ }^{3}$ \\ ${ }^{1}$ Quantitative Research Manager and Specialist, Canadian Hub for Applied and Social Research, University of \\ Saskatchewan, Saskatoon, SK, Canada \\ ${ }^{2}$ Professor, Department of Agricultural and Resource Economics, University of Saskatchewan, Saskatoon, SK, \\ Canada \\ ${ }^{3}$ Professor, Department of Soil Science and Agri-Food Engineering, Laval University, St. Foy, P.Q., Canada \\ Correspondence: Suren Kulshreshtha, Department of Agricultural and Resource Economics, University of \\ Saskatchewan, Saskatoon, SK, Canada. Tel: 1-306-966-4014. E-mail: suren.kulshreshtha@ usask.ca
}

Received: August 28, 2021 Accepted: October 6, 2021 Online Published: October 27, 2021

doi:10.5539/sar.v10n4p13 URL: https://doi.org/10.5539/sar.v10n4p13

\begin{abstract}
At a global scale, Canada is the second largest cranberry producer, with Quebec being the largest producing region within Canada. Efficient water use in agricultural production has long been a topic of outmost importance to agricultural producers, and governing bodies. The immediacy of climate change effects sped up the need to find solutions that conserve water. One such promising technology is irrigation using real-time tensiometers, which provides rapidly critical irrigation needs information to producers. Adoption of improved technologies by farmers is dependent on the effect it has on the farms' bottom line. In this study, we examine the financial performance of real-time tensiometer based irrigation, and compare it to evaporation needs based irrigation (baseline), in the context of a Quebec-based cranberry farm. Our findings show that irrigating using real-time tensiometers technology generated higher economic returns. With a net present value of $\$ 96,847$, this technology increased returns by nearly $53 \%$ compared to the baseline technology. Subsequent sensitivity analyses confirmed the robustness of these findings, even when changing important farming parameters.
\end{abstract}

Keywords: horticulture; irrigation, efficient water use, farm economic analysis, beneficial management practices, climate change adaptation

\section{Introduction}

Irrigation and drainage practices are necessary to produce high value horticultural crops, such as cranberries. With an increasing population, and a decrease in water resources brought forward by climate change and competing uses from other sectors, ways to supplement water availability to crops is considered to be essential. There is also a concern that water for irrigation purposes might be less readily available in the future. This situation can pose serious economic risks to agricultural producers and environmental risks to habitats and ecosystems. Farmers' adoption of improved water management practices or technologies can be both a mitigation of environmental impacts strategy and an adaptation to a changing environment by using water resources more efficiently.

Across Canada, and in Eastern Canada in particular, efforts have been made to develop improved technologies and management practices, beneficial management practices (BMPs) that could be implemented with or without government support (such as through cost-share programs). Such BMPs are intended to minimize the negative impacts of agricultural production on the environment. For farmers to be favourably disposed to their adoption, financial gains are important. Agricultural producers across Canada, also acknowledge their responsibility to care for natural resources (Environics, 2006). This is a favourable factor for adoption of such BMPs but results in uncompensated on-farm costs and off-farm benefits, which could become inhibitors of BMP adoption. Past experiences and historical data on adoption of these BMPs, in the context of Canadian agriculture, confirm that while some agri-environmental practices (especially those showing positive economic outcomes) were adopted more rapidly and more widely, while others tended to be modestly adopted and with insufficient effects in reducing the degradation of the environment (MacKay et al., 2010; Eilers et al., 2010; Council of Canadian 
Academies, 2013).

This study evaluates the economic returns associated with cranberry production under two distinct scenarios - a status quo or baseline scenario and the improved water management scenario also referred to as the BMP scenario.

Currently, most producers in the study region employ a method of production with no soil water control, with cranberry irrigation done based on evapotranspiration needs of the crop. In other words, producers supply water to the crop based on evapotranspiration estimate, neglecting the water which can come from horizon through capillary rise (Caron et al., 2017). In this study, we refer to this method of irrigation as the baseline technology.

The BMP technology uses water control methods where real-time tensiometers are used to assess water needs during plant growth. Without this technology, producers irrigate cranberries on a continual basis without any regard to water table.

The major objective of this study is to investigate financial returns to producers by adopting the BMP Technology and compare it to that of their Baseline Technology. This study was devoted to cranberry farms in the province of Quebec, Canada.

\section{Literature Review}

\subsection{Climate Change and Quebec Agricultural Production}

Most of Québec's agricultural production takes place in the southern part of the province, within the St. Lawrence River Basin. Water sources for agriculture in Québec are diverse and include both surface water and groundwater. According to a recent report, the southwest part of the province is already experiencing pressure on water resources (Council of Canadian Academies, 2013).

Québec is also likely to encounter challenges in the agricultural sector, brought forward by a changing climate. In the southern part of the province, mean annual temperatures have increased up to $1.2^{\circ} \mathrm{C}$, between $1960-2003$ (Lemmen et al., 2008; Yagouti et al., 2006). Climate projections indicate that by 2050, the annual temperatures will have increased from between $2^{\circ} \mathrm{C}$ to $5^{\circ} \mathrm{C}$ in the southern regions of Québec, from the baseline period of 1961-1990 (Lemmen et al., 2008).

Climate related changes are expected to hinder certain segments of agricultural production while helping others. Cranberry production is water intensive. In addition to this, most of the production in the province takes place in one region, making production reliant on the same surface water resources. To compensate for that and to ensure that a minimum in-stream flow remains intact, the Ministry of Environment requires producers to apply for pumping authorizations. This would likely alleviate some threats, but it does not extend to growers who had water withdrawal rights prior to the change in legislation (Caron, 2017). In the case of cranberry production in Centre-du-Québec, climate change could further exacerbate these issues related to water availability.

\subsection{Cranberry Industry in Canada}

On an international scale, in 2015, Canada was ranked second largest cranberry producer in the world accounting for $28 \%$ of the world cranberry production. In comparison, U.S.A held $68 \%$ of the world production share, whereas Chile's market share was $4 \%$ (Deloitte, 2016). Canada is a net cranberry exporter, with exports totalling \$124.5 million in 2016, and imports of only \$6.1 million (MAPAQ, 2018). Québec is the largest cranberry producer within Canada, producing over $65 \%$ of the total production of 158,827 metric tonnes. British Columbia, accounts for nearly $29 \%$ of cranberry production (MAPAQ, 2018).

Centre-du-Québec is the largest producing region in the province, accounting for $90 \%$ of the provincial cranberry production. However, even within this region most growers are located in the rural municipalities of L'Erable and Arthabasca. The area dedicated to this fruit's production increased six-fold between 1996 and 2018. In 2018, 2,655 ha were under cranberry production in Quebec, compared to less than 400 ha in 1996 (APCQ, 2019). Figure 1 shows the production trends in terms of area cultivated and harvested volume in Québec, between 1996 and 2019. 


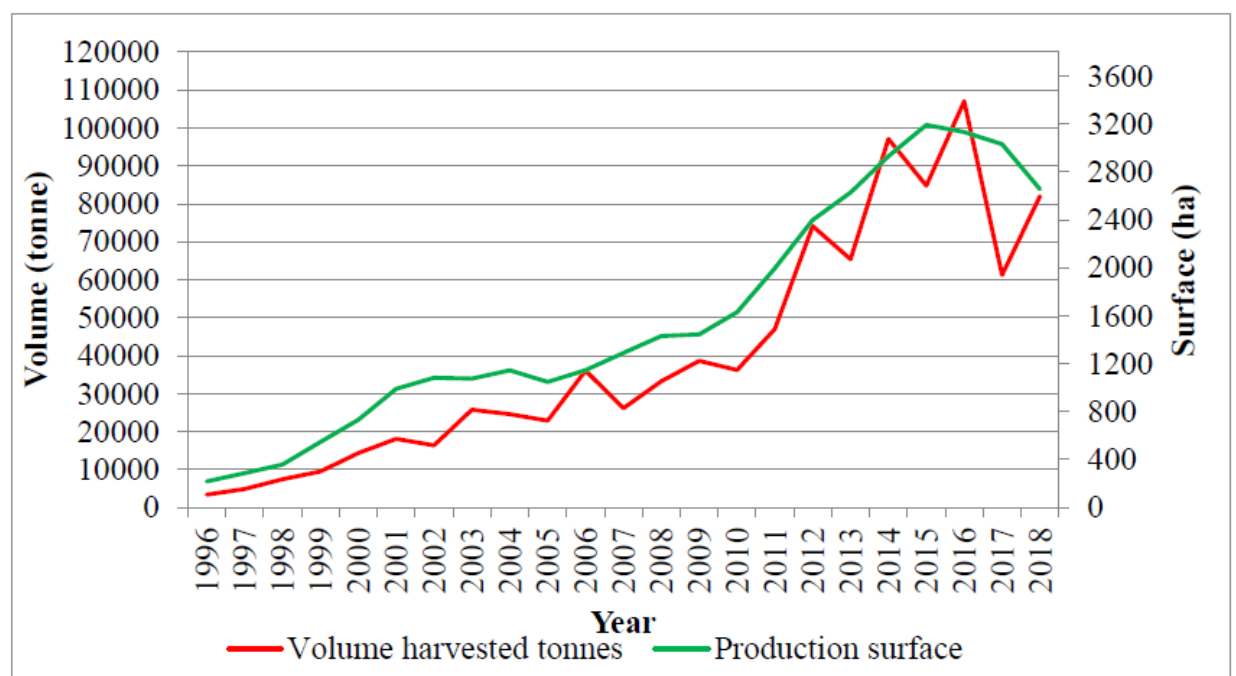

Figure 1. Trend in cranberry production area and harvested volume, Québec 1996-2018

Source: APCQ (2019)

Altogether, in 2018 there were 78 growers producing over 82 thousand tons of cranberries (APCQ, 2019). In terms of farm gate values, this production was valued at over $\$ 64$ million dollars in 2017 (Statistics Canada, 2019). Over the last two decades, yields have been generally following an upward trend (Figure 2). The average yield in the province between 2008 and 2018 was around 27,000 kg/ha (APCQ, 2019).

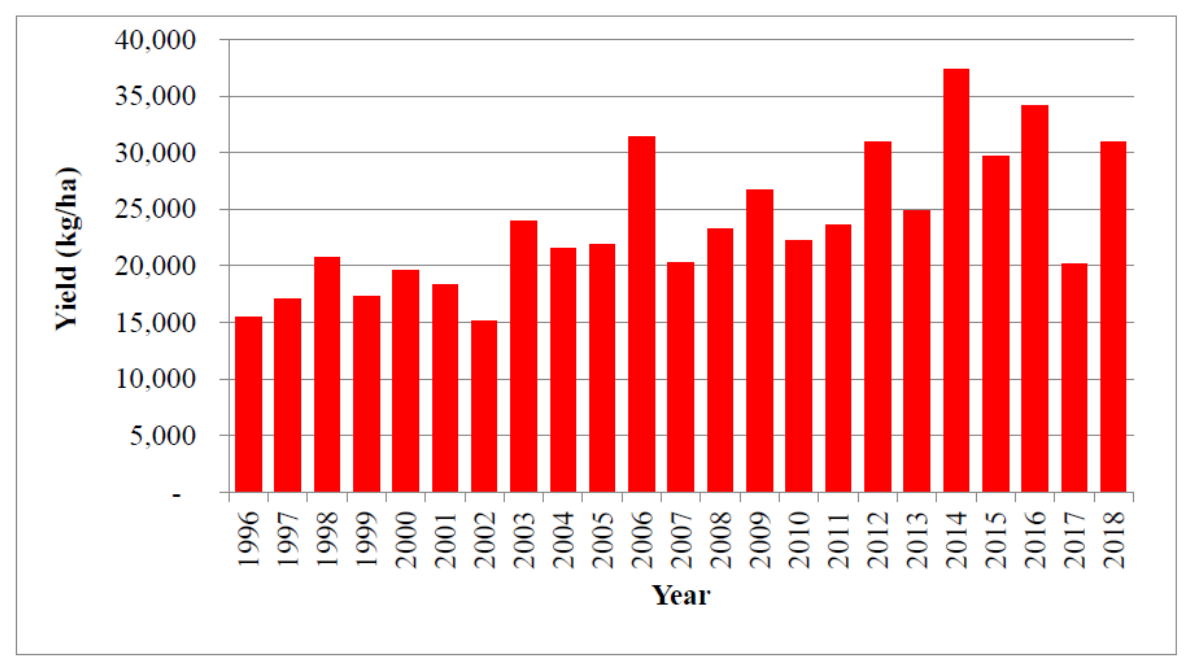

Figure 2. Growth pattern in cranberry average yields, Québec 1996-2018

Source: APCQ (2019), based on average of producer yields

While cranberry demand has increased in the last few years (in part due to research findings indicating additional health benefits, but also due to innovative industry marketing), cranberry prices have been plummeting. The accumulation of large cranberry stocks explains in part the observed price drop. This is one of the many challenges faced by growers in recent years. In the mid 90 , the price of cranberries was $\$ 2.19 / \mathrm{kg}$, which decreased to $\$ 0.10 / \mathrm{kg}$ in 2015 (Figure 3). Price received by producers vary depending on the processor, processing destination of the fruit, and the quality of the fruit, as a producer can receive a bonus of up to $\$ 0.018 / \mathrm{kg}$, generally based on the colour of the fruit (M. Thomas, personal communication, December 2, 2014). The largest cranberry cooperative Ocean Spray influences cranberry prices at the international and regional level. When cranberry prices are low, processors are incentivized to increase their inventories above average, in anticipation of a price increase. However, this strategy had a negative effect on the prices both for growers and for processors (Alston et al., 2014). 


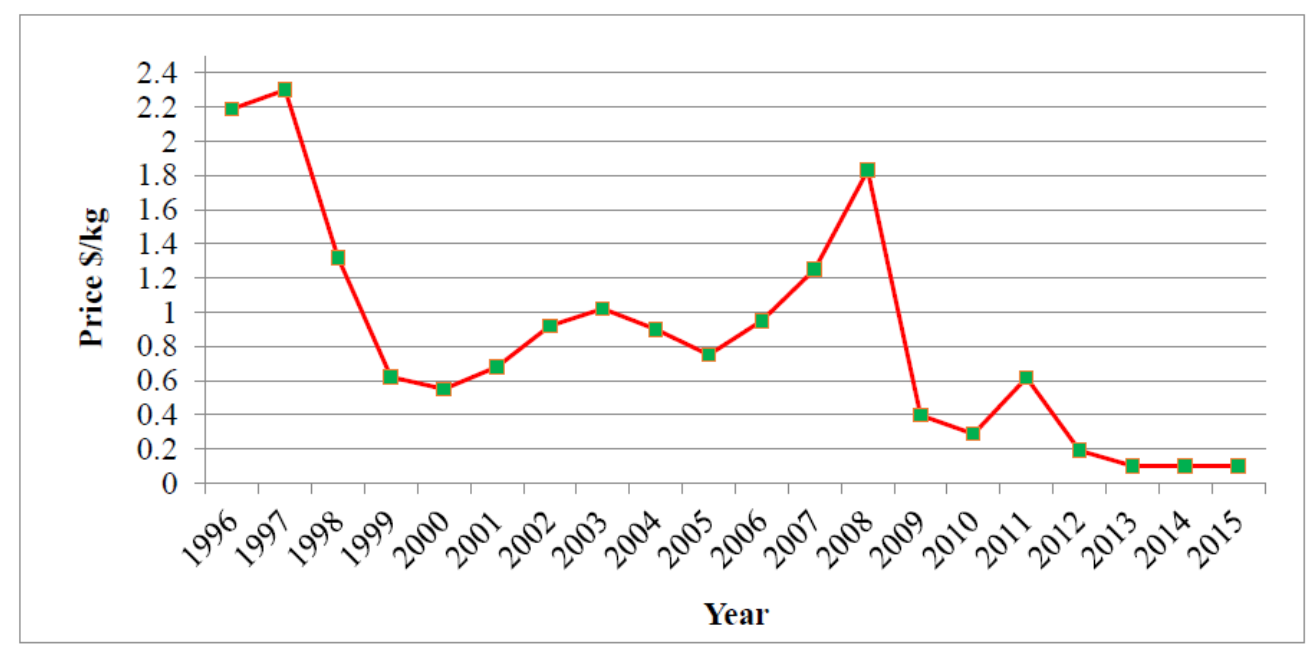

Figure 3. Historical trend in cranberry average prices, Québec 1996-2015

Source: APCQ (2019)

Note: Prices are in current Canadian dollars, as received by producers.

Quebec farms reporting cranberry cultivation vary in size from only 1.5 ha to over 560 ha. Approximately 59\% of farms were of less than 160 ha, 37\% are between 160 and 250 ha, and only a small portion (more precisely 4\%), were over 450 ha in total farm size (Statistics Canada, 2011). Thus, most farms are of smaller size, where financial considerations are important.

Cranberries are predominantly consumed in the form of juice, which constitutes roughly $70 \%$ of the international market. However, there is a market for fresh and dried cranberries as well - a segment of the industry that has seen some growth in more recent period. In Québec, most of the cranberries are processed into dried fruit (nearly $60 \%$ ) and the rest is processed mostly into juice concentrate (nearly $40 \%$ ). In addition to that, a very small percentage is sold as fresh fruit (Poirier, 2010). Most of the regional production (more precisely 95\% of the total) is bound for the United States' market. Approximately 70\% of Québec's cranberries are processed in local facilities. The largest regional processors are Canneberges Atoka Inc., Fruit D'Or (also the largest organic processor in North America), La Maison Bergevin and Canneberges L\&S. Local processors sign contracts with the growers, of anywhere between 3 to 5 years in duration. The rest of the regional production is processed in the United States through the Ocean Spray Cooperative.

\subsection{Water Use in Cranberry Production}

Availability of water represents a critical factor in cranberry production. Irrigation in cranberry production serves multiple purposes. It can fulfill additional water requirements for the plant, alleviate heat stress, and provide frost protection. Beyond irrigation, water is also used for flooding during the harvesting stage and for protecting the plant over the winter. The cranberry growing season averages 150 days, during which time, average water requirements are $62 \mathrm{~mm}$ per month, with peak requirements of $102 \mathrm{~mm} / \mathrm{month}$ under extreme conditions (Caron, 2009).

As the Centre-du-Québec, the region where cranberry production is concentrated, receives at least $95 \mathrm{~mm}$ in July - the driest month, irrigation is necessary. In addition to irrigation, water is used for flooding at the beginning of winter, in early spring, and for harvest. The cranberry basin or cultivation beds are flooded with water, reaching depths between 30 to $40 \mathrm{~cm}$. Cranberry production is water intensive, it was estimated that on a yearly basis it requires 15,000 to $25,000 \mathrm{l} / \mathrm{ha}$ (Eck, 1976). However, not all water used is consumed. It was estimated that over half of it is recycled and reused or released back into the original water body.

Water management in cranberry production is complex and relies on a diversity of technologies and practices. In cranberry production, drainage management and water table depth are closely linked to management of irrigation (Sandler et al., 2004). Most growers use a sprinkler system for irrigation purposes. The nozzles are located within the cranberry beds, a few centimetres above the ground, between 15 and 18 meters apart (Pelletier et al., 2015). Water travels from the reservoir - usually located at higher elevation on the farm, into the field by making use of gravitational force. While gravity moves the water from the main reservoir to the cranberry bed requiring irrigation, the sprinkler system receives water with the use of irrigation pumps. 
Another method of irrigation used by cranberry growers is sub-irrigation. Sub-irrigation is a dual-purpose water management system that provides both irrigation and drainage. Additional water can be supplied through the same pipes that are used for drainage. The water table depth is regulated with the use of control structures. To maintain an appropriate water table depth, water is supplied under the surface, to provide ideal moisture conditions in the effective root-zone (Handyside, 2003). During the growing season and especially after heavy rain events, the drainage system becomes a very important component of the water management system.

Irrigated plots are also equipped with drains, good drainage of the cultivated beds helps prevent fungal development, salinity issues and decreased yields. Drainage is also used to lower the water table during spring snowmelt and after harvest. This is realized with subsurface drains and surface ditches available under and along each field (Roper and Vorsa, 1997). To manage water resources, some growers use tensiometers, which is a tool used to indicate the water available to the plant in the soil.

\subsection{Characteristics of Cranberry Production}

Historically, cranberries (Vaccinium macrocarpon Aiton) have been grown in wetland habitats in certain parts of North America. Now their commercial production has taken place in upland areas on sandy mineral soil beds, purposefully created with low-permeability and surrounded by water management systems that include water canals for drainage, dikes for water retention, and control structures for water level management.

Cranberry is a perennial plant (called lowbush). In Québec 75\% of the fruits grown belong to the Stevens cultivar - a hybrid developed in 1950 (Roper, 2008). Worldwide this type of cranberries accounts for nearly half of total cranberry production (Averill et al., 2008). The plant requires well-drained and acidic soils (pH levels between 4 and 5), a cool climate, and good drainage and irrigation management (Poirier, 2010).

The growing season ranges between April and September. The cranberry plant is a low growing, trailing and with a woody vine, which spreads horizontally through runners. Vines form a thick mat, covering the entire surface of the cultivated bed (Sandler and DeMoranville, 2008). The runners send out uprights -- vertical branches, which can produce flowering (fruit bearing) and vegetative buds. By mid-June, the flowering period begins, and the plant requires pollination for better fruit yields. Berries develop between the end of June and beginning of July and require, on average, 80 days ripening (Sandler and DeMoranville, 2008). Harvest usually takes place between September and October (APCQ, 2018).

Cultural practices related to cranberry production take place throughout the growing season. The preparation for the growing season begins in winter, soon after harvest. To protect the plants from frost damage, the fields are flooded with water in December, and later a layer of sand is spread on the surface of the bed. The sanding supports a healthy development of the plant, helps increase yields, and reduces pests (APCQ, 2018). In spring, floodwater is removed, and the plant leaves the dormancy stage. Sprinkler irrigation is used to protect the plant from frosting, but there are growers who also choose to flood the beds for a second time, between mid-April and mid-May. In the spring, herbicides and fertilizers are applied, and in May new vines can be planted. Throughout the summer, cranberries might require irrigation. Between mid-June and July, beehives are hired to help pollinate cranberry flowers. In the fall, the sprinklers are also used to avoid frost damage, if needed.

\section{Study Methods}

\subsection{Research Site}

The study cranberry farm located in Saint-Louis-de-Blandford, Centre-du-Québec region, in Québec. The farm has approximately 567 ha dedicated solely to cranberry production. On this farm, the Stevens cranberry variety is grown, which is the most predominant cultivar grown in North America. The cranberry production takes place in rectangular basins, also referred to as cranberry beds, which are half a meter deep. This cranberry bog basin dimensions are approximately $50 \mathrm{~m}$ by $500 \mathrm{~m}$; the original soil was excavated and was replaced by sandy soil that has better drainage characteristics, which on a typical cranberry farm is between $15-60 \mathrm{~cm}$ in thickness (Caron et al., 2017). Other producers in the region have similar production layouts and practices.

Drainage tiles were installed across the entire production area. Within each basin, there are three drainage tiles located at $20 \mathrm{~cm}$ underneath the soil surface. Drainage is also achieved via surface ditches, located at each edge of the cranberry fields. The main water source is the Becancour River. On the cranberry fields, a sprinkler irrigation was used to meet plants' water requirements during the summer, and for plant frost protection in late fall and early spring. To meet the plants' water requirements, irrigation scheduling was done with the use of real-time tensiometers - devices that provide soil moisture readings.

At this site, two water management systems were evaluated: sprinkler irrigation and subirrigation. The latter is a dual-purpose water management system, which provides both irrigation and drainage. Additional water for 
irrigation can be supplied through the same pipes that are used for drainage. Optimal use of subirrigation is achieved when the water table is accurately managed. The existing drainage system for cranberry production was modified, to make subsurface irrigation a feasible option. Control structures and pumps required to move the water in and out of each cranberry basin were required for subirrigation. In some cases, the modification of the current drainage system involved only the installation of additional pipelines. Pelletier et al. (2013, 2015, and 2016) have provided additional information on the in-field research design at this site.

\subsection{Study Scenarios}

The Baseline Technology reflected the effects of growing cranberries under a relatively wet water management strategy, without water table control, it could be called a wet-method technology. The BMP Technology represented a drier water table management strategy, where tensiometers were used to assess water needs. This terminology was chosen as the wireless tensiometer generated important water savings. Rest of the cultural practices remain the same under both the technologies. To better distinguish between these two technologies, in this study they will be referred as the Baseline Technology, and the BMP Technology.

\subsection{Financial Analysis}

This study evaluated economic performance of the above two technologies from a producer's accounting stance - in other words, only the financial transactions borne by the producer were included. External costs and benefits to other producers in the region and to society-at-large were considered not eligible in this analysis, and thus excluded.

Gains in economic efficiency of the producer were measured using two criteria: net present value (NPV) and benefit-cost ratio (BCR). A cranberry farm, located in Saint-Louis-de-Blandford, Québec represented an average producer in the region. To evaluate the financial desirability of investments, production budgets were developed for each of the technologies using CRAAQ (2017) and APCQ (2019) data. According to CRAAQ (2017) for every hectare under cranberry production, three additional hectares are required for additional farm infrastructure (i.e., drainage system, water reservoirs, etc.). For example, CRAAQ developed a cost of production budget for a regional representative cranberry farm. This farm was of 195 ha, of which only 65 ha were devoted for cranberry production (CRAAQ, 2017).

In this study, the total area of the study farm was 567 ha in size, located in Saint-Louis-de-Blandford, Québec. Given the distribution of Quebec cranberry farms, it is a large farm and may not be considered a representative one for the region. The farm is dedicated exclusively to the cultivation of cranberries, as they are not grown in a crop rotation. In this study, economic analysis was based on a cranberry area of approximately 80 ha - about $14 \%$ of the total farm size.

The producer used a sprinkler system throughout the production area to irrigate and for frost protection. The cranberry beds were surrounded by ditches, which together with the drainage system and water control structures, allow for water table management. Historically, the producer was using only sprinkler irrigation without consideration of the upward flux from the water table. The plots were irrigated two hours every other day without monitoring the water table depth. Recently, the producer started to use real time tensiometers to control water table depths and to trigger irrigation (Caron et al., 2017). A field experiment conducted by Pelletier et al. (2015), during the 2011 and 2012 growing seasons, showed that the producer's practice of irrigating cranberry fields every other day for 2 hours exceeded plant water requirements. Over-irrigated soils create wet conditions, which deprive the roots of oxygen, negatively affecting cranberry yields. Only recently, the producer improved the drainage system on a subsection of the farm, together with the introduction of tensiometers, in order to improve water table management and to trigger irrigation more accurately.

Under the Baseline Technology, assumptions regarding water included: (i) Grower irrigates twice every other day; (ii) Subsurface drains are installed 10m apart; (iii) No device is used to inform the triggering of irrigation; and (iv) Sprinkler irrigation system is used for irrigation. In the BMP Technology, cranberry production was under an optimal, or a relatively drier, water management treatment. Furthermore, it was assumed that most of the infrastructure remained the same, apart from irrigation triggering and subsurface drainpipes distancing. In terms of irrigation triggering, the assumption made was that the grower changed to using real time wireless tensiometers (model HXM80, Hortau, Lévis, Canada).

The BMP Technology related water management systems consisted of a water reservoir located on the highest elevation point of the farm. The reservoir is filled by precipitation and water from the Becancour River with the use of a water pump. The cranberry fields were supplied gravitationally with water, via the main canal. From the canal, a main pipeline brings the water into the cranberry beds, via lateral pipelines. There were few areas on the 
farm where a low flow pump is needed for water to reach the main pipeline. For each bed, there were three laterals, $15 \mathrm{~m}$ apart, with 25 sprinkler heads on each one of the laterals. It was assumed that for the BMP Technology, the grower had to install more drainpipes, which led to an increased cost of investment and a loss of yield of $10 \%$ over the first two years following new drains installation. These impacts are similar to those reported by Jabet et al. (2016). Image of the sprinkler irrigation system and a water collection reservoir, which is the place where water is decontaminated of pesticides and then released in river, or most times recirculated and reused on the farm, is shown in Figure 4. Further assumption made included a 5\% rate of discount, and a project life of 20 years, plus the new investment being financed through equity capital.

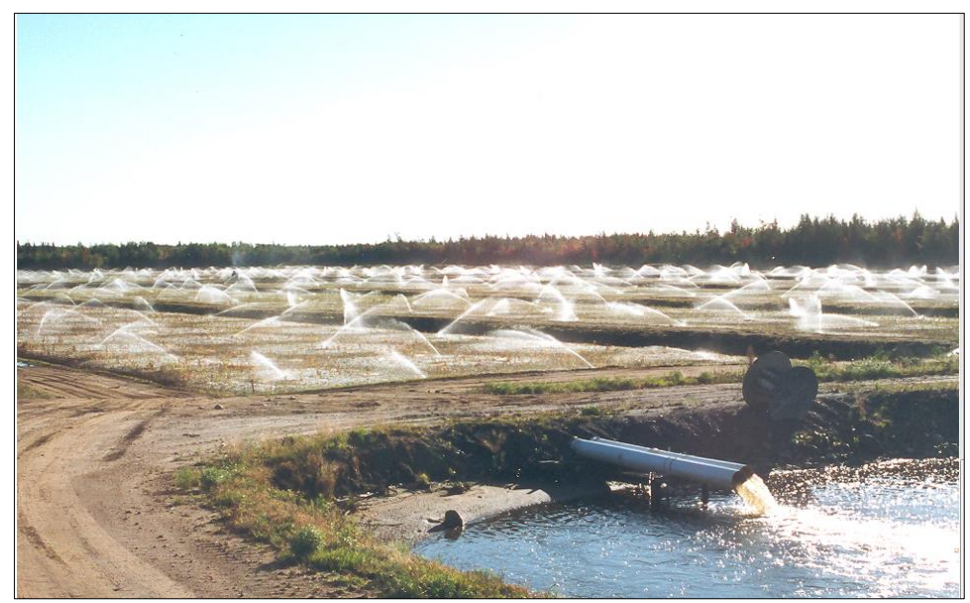

Figure 4. Sprinkler irrigation system and field drainage to collection pond

Source: APCQ (2018)

\subsection{Estimation of Economic Variables}

\subsubsection{Cost of Investment}

As noted earleir, the cost of investment associated with these two water management systems were based on a cranberry area of 80 ha were both technologies. The investment cost for the baseline system was $\$ 5,575 \mathrm{ha}^{-1}$, whereas for the BMP system, this cost was $\$ 7,281 \mathrm{ha}^{-1}$ ). The cost of investment was derived using the producers layout and specifications, and using price guideline document, AGDEX 233/821, developed by CRAAQ (2017), and through work of Jabet et al. (2016), Pelletier et al. (2013, 2015) and Caron et al. (2017). The cost of tensiometers was derived from a personal communication with C. Letendre from Hortau, Lévis located in Québec and Jabet et al. (2016).

Table 1. Cost of investment for baseline and BMP system for cranberry production $\left(\$ \mathrm{ha}^{-1}\right)$

\begin{tabular}{lll}
\hline Cost Items & Baseline Technology & BMP Technology \\
\hline Drainage system & $\$ 659$ & $\$ 1,899$ \\
Water reservoir & $\$ 1,131$ & $\$ 1,131$ \\
Irrigation system & $\$ 1,558$ & $\$ 1,558$ \\
Field water control structures & $\$ 551$ & $\$ 551$ \\
Reservoir water control structures & $\$ 242$ & $\$ 242$ \\
Ditch water control structures & $\$ 72$ & $\$ 72$ \\
Irrigation pump (diesel) & $\$ 570$ & $\$ 570$ \\
Low lift pump (diesel) & $\$ 793$ & $\$ 793$ \\
Tensiometers Monitoring Station & & $\$ 304$ \\
Web Base & & $\$ 89$ \\
Repeater & & $\$ 52$ \\
Installation Fee Monitoring Station & & $\$ 12$ \\
Installation Fee Web Base & & $\$ 7$ \\
Installation Fee Repeater & $\mathbf{\$ 5 , 5 7 5}$ & $\mathbf{\$ 7 , 2 8 1}$ \\
Total Costs & & \\
\hline
\end{tabular}




\subsubsection{Estimated Revenue}

Similar to other crops, revenues from cranberry production are affected by two major factors - yield and cost of production. Although price is also a major factor, it was assumed to be a given fact, except that a sensitivity analysis was undertaken for different levels of price of cranberries.

\subsubsection{Direct impact of Adopting the BMP}

Through adoption of the BMP Technology for producing cranberries, both cost and revenues are affected. The latter is affected through a change in the yield, whereas the former through additional infrastructure to be added with the control system. Yield of cranberries are affected both by dry conditions or excess moisture conditions (Figure 5).

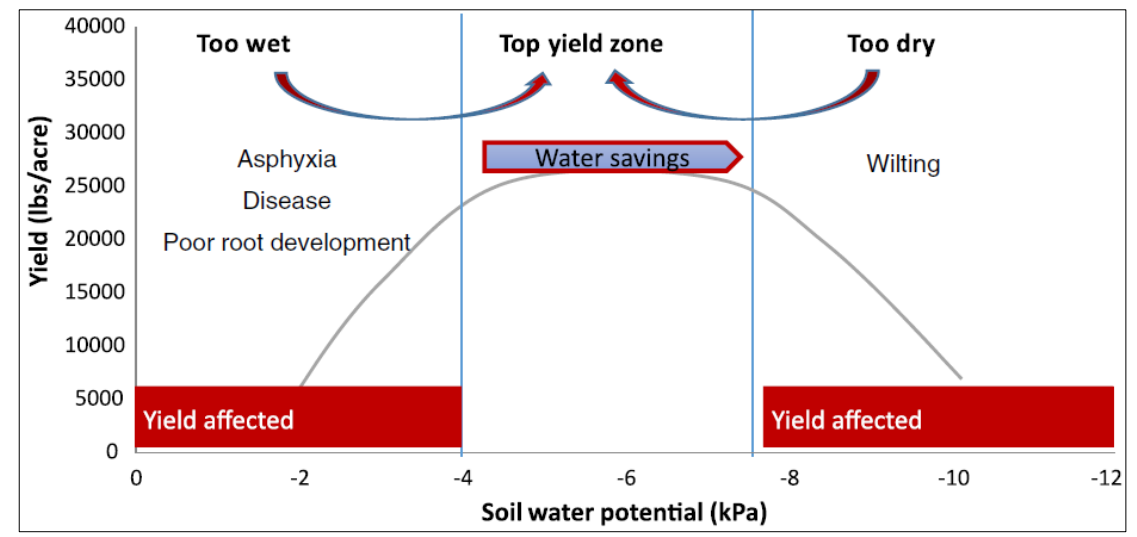

Figure 5. Cranberry yield variability associated with soil water potential

Source: Jabet et al. (2016)

Effect on crop yield: Keeping water table levels in the optimal range, increases cranberry yields, when compared to a relatively high-water table management strategy. Several researchers evaluated yield differences between optimal and relatively wet water management conditions in cranberry production and found consistent results. According to et al. (2015), the average yield on a 5-years period prior, under the grower's traditional water management practice, was $39,230 \pm 6,697 \mathrm{~kg} / \mathrm{ha}$. In 2014, with optimal water management, cranberry yield increased by $51 \%$ to $59,295 \pm 3,215 \mathrm{~kg} / \mathrm{ha}$. Poor drainage in cranberry fields affecting yield is also reported by Jabet et al. (2016). Improving sub-optimally drained field has been shown to increase cranberry yields by 5,588 $\mathrm{kg} / \mathrm{ha}$.

For the Baseline Technology, it was assumed that cranberry yields were $35,000 \mathrm{~kg} / \mathrm{ha}$, which represented the growers' average over the last four years before any changes in the water management system were made. Under the BMP Technology, only a $16 \%$ yield increase was assumed, which is a similar increase to the one used by Jabet et al. (2016). Results are summarized in Table 2.

Table 2. Difference in revenue and cost under the baseline and BMP System for cranberry production, 2015 $\left(\$ \mathrm{ha}^{-1}\right)$

\begin{tabular}{llll}
\hline Particulars & Baseline Technology & BMP Technology & Difference (BMP - Baseline) \\
\hline $\begin{array}{l}\text { Revenue } \\
\text { Gross Revenue }\end{array}$ & $\$ 15,919$ & $\$ 18,519$ & $\$ 2,600$ \\
$\begin{array}{l}\text { Costs } \\
\text { Land Preparation }\end{array}$ & $\$ 835$ & & $\$ 0$ \\
Cultural Practices & $\$ 2,701$ & $\$ 835$ & $\$ 0$ \\
Irrigation Costs & $\$ 1,798$ & $\$ 2,701$ & $\$ 0$ \\
Harvesting & $\$ 770$ & $\$ 1,459$ & $\$ 338)$ \\
Other Costs & $\$ 1,042$ & $\$ 770$ & $\$ 0$ \\
Total Variable Costs & $\$ 7,146$ & $\$ 1,185$ & $\$ 143$ \\
Total Fixed Costs & $\$ 3,620$ & $\$ 6,951$ & $\$ 195)$ \\
Total Costs & $\mathbf{\$ 1 0 , 7 6 5}$ & $\$ 3,620$ & $\$ 0$ \\
Net Revenues & $\mathbf{\$ 5 , 1 5 3}$ & $\mathbf{\$ 1 0 , 5 7 0}$ & $\mathbf{\$ 1 9 5 )}$ \\
\hline
\end{tabular}


Effect on cost of production: Cranberry costs of production were estimated using data provided by the grower. The baseline budget was calculated using the average of the 2011-2014 production period using data produced by CRAAQ (2017). The BMP affected the cost of production through irrigation cost. Based on average summer rainfall calculation, about $441 \mathrm{~mm}$ (equivalent to $74 \%$ of amount of water used under wet treatment) of water is saved expected under a dry treatment $(152 \mathrm{~mm})$ when compared to a wet treatment $(593 \mathrm{~mm})$ (Pelletier et al., 2013; Jabet et al., 2016). The annual irrigation costs per ha under the Baseline Technology were estimated to be $\$ 1,798$, which reduced to $\$ 1,459$ under the BMP Technology. Both labor and energy costs were included in these estimates. These values suggest that there is a reduction of $\$ 339 \mathrm{ha}^{-1}$ in costs under an improved water management technology over the baseline.

Both technologies are similar except for revenues, cost of irrigation, other costs and initial cost of investment. As shown in Figure 6, cultural practices account for over 38-39\% of the total costs of production, followed by irrigation costs. In fact, irrigation costs constituted $25 \%$ of the total cost under the Baseline Technology, which was reduced to $21 \%$ under the BMP Technology.

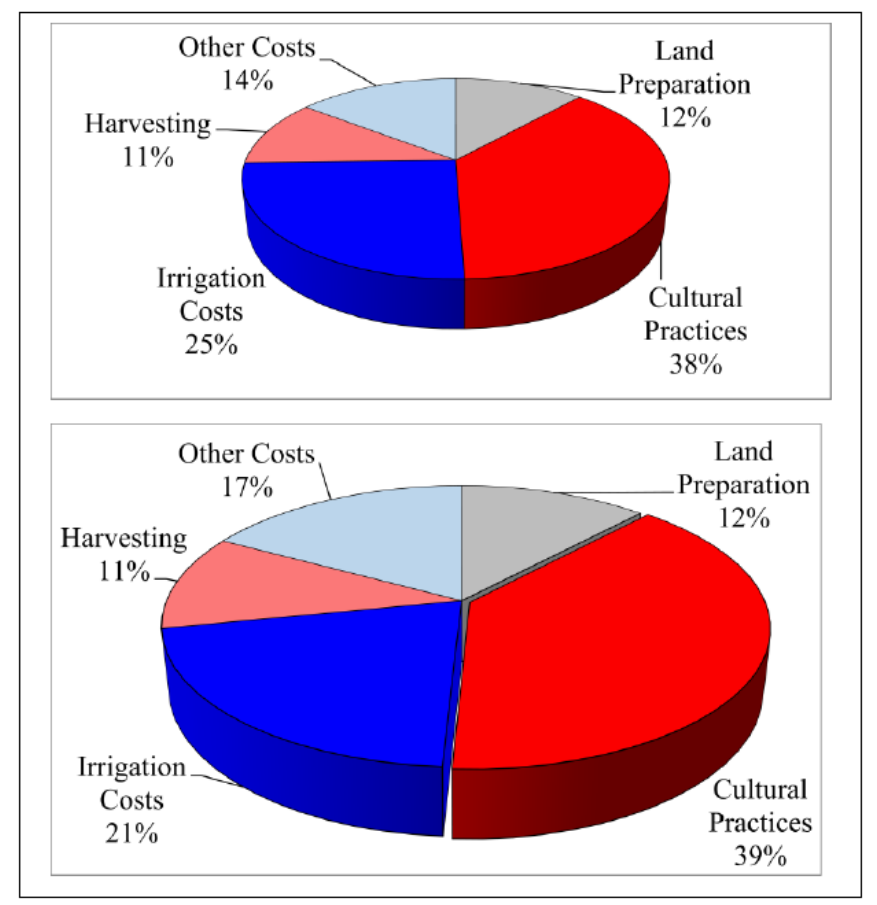

Figure 6. Distribution of total cost by major cost categories with baseline technology (top) and BMP technology (bottom) for cranberry production

\section{Results}

\subsection{Economic Desirability of BMP}

As noted above, two financial indicators were estimated for the BMP Technology and compared with those for the Baseline Technology. Based on both the criteria - NPV and BCR, the BMP technology outperformed the Baseline Technology (Table 3). Under a drier water management regime, the net present value per ha was estimated at $\$ 33,390$, almost 53\% higher than that under the Baseline Technology. These results are based on a discount rate of $5 \%$, project life of 20 years, and that the producer did not acquire a loan for financing the project.

Table 3. Measures of financial desirability of baseline and BMP systems for cranberry production $\left(\$ \mathrm{ha}^{-1}\right)$

\begin{tabular}{|c|c|c|}
\hline Particulars & Baseline Technology & BMP Technology \\
\hline Present Value of Benefits* & $\$ 214,309$ & $\$ 249,316$ \\
\hline Present Value of Costs* & $\$ 150,852$ & $\$ 152,469$ \\
\hline Benefit Cost Ratio & 1.42 & 1.64 \\
\hline Net Present Value* & $\$ 63,457$ & $\$ 96,847$ \\
\hline
\end{tabular}




\subsection{Sensitivity Analysis}

Although the results of the economic analysis indicated a better economic performance of the BMP, these results could change under different economic and non-market conditions. To test for the robustness of this conclusion, sensitivity analysis was undertaken. Parameters included for this analysis were: change in crop yields, change in product prices, change in climate as reflected in amount of rainfall, project investment cost, and discount rate.

\subsubsection{Sensitivity to Change in Crop Yields}

Cranberry yields can be affected by pruning of the plant, natural plant development, drainage system maintenance (i.e., unclogging), among others. Because of lack of better data, it was assumed that the yields under the improved water management system would increase only by $5 \%$, followed by a $10 \%$ and $15 \%$ increase. Results suggest that the BMP Technology continues to be more economically efficient when compared to the Baseline Technology, even when the yield increases are in the magnitude of 5\% (Table 4). Comparatively, the BMP Technology increased the NPV by over 14\% over the baseline practice. An increase in the benefit-cost ratio was also obtained for the BMP Technology. Thus, on the basis of both of these criteria, the BMP Technology was found to be preferrable on economic grounds.

Table 4. Comparison of financial performance baseline and BMP system at different cranberry yields $\left(\$ \mathrm{ha}^{-1}\right)$

\begin{tabular}{lllll}
\hline Particulars & Baseline & \multicolumn{3}{l}{ BMP Technology } \\
\cline { 3 - 5 } & Technology & $5 \%$ & $10 \%$ & $15 \%$ \\
\hline Present Value of Benefits* & $\$ 214,309$ & $\$ 225,025$ & $\$ 235,738$ & $\$ 246,454$ \\
Present Value of Costs* & $\$ 150,852$ & $\$ 152,469$ & $\$ 152,469$ & $\$ 152,469$ \\
Benefit Cost ratio & 1.42 & 1.48 & 1.55 & 1.62 \\
Net Present Value* & $\$ 63,457$ & $\$ 72,556$ & $\$ 83,269$ & $\$ 93,985$ \\
NPV difference from Baseline & & $\$ 9,099$ & $\$ 19,812$ & $\$ 30,528$ \\
NPV increase from baseline & & $14.34 \%$ & $31.23 \%$ & $48.11 \%$ \\
\hline
\end{tabular}

* At $5 \%$ rate of discount

\subsubsection{Sensitivity to Change in Crop Price}

Depending on the processed product and fresh product market conditions, the price of cranberries can fluctuate. In the base analysis, the price for frozen berries was assumed to be $\$ 0.45 / \mathrm{kg}$, and $\$ 1.08 / \mathrm{kg}$ for the fresh market cranberries. One of the main concerns of producers has been the almost continual decline in cranberry prices (as shown in Figure 2.6), which was also confirmed by regional agricultural experts. To understand the potential effect of a change in prices on profitability, a decrease of up to $20 \%$ in cranberry prices was assumed. The NPV values were re-estimated under this assumption. As expected, NPV decreases as cranberry prices decrease. However, even then, both water management systems remain profitable, although the gap between NPV values for the two technologies increases. When prices decrease of $20 \%$ was assumed, (i.e., $\$ 0.36 \mathrm{~kg}^{-1}$ for frozen berries, $\$ 0.86 \mathrm{~kg}^{-1}$ fresh market and $\$ 0.03 \mathrm{~kg}^{-1}$ premium price), the NPV increase for the BMP Technology over the Baseline Technology was of $83 \%$ (Table 5).

Table 5. Comparison of baseline and BMP systems at different cranberry prices, $\$ \mathrm{ha}^{-1}$

\begin{tabular}{|c|c|c|c|c|c|}
\hline \multirow[t]{2}{*}{ Particulars } & \multicolumn{5}{|c|}{ Change in price from Base } \\
\hline & Base & $-5 \%$ & $-10 \%$ & $-15 \%$ & $-20 \%$ \\
\hline & \multicolumn{5}{|c|}{ Baseline Technology } \\
\hline Present Value of Benefits* & $\$ 86,795$ & $\$ 83,573$ & $\$ 80,350$ & $\$ 77,128$ & $\$ 73,906$ \\
\hline Present Value of Costs* & $\$ 61,095$ & $\$ 61,095$ & $\$ 61,095$ & $\$ 61,095$ & $\$ 61,095$ \\
\hline Benefit- Cost Ratio & 1.42 & 1.37 & 1.32 & 1.26 & 1.21 \\
\hline Net Present Value* & $\$ 63,457$ & $\$ 55,499$ & $\$ 47,543$ & $\$ 39,588$ & $\$ 31,632$ \\
\hline \multicolumn{6}{|c|}{ BMP Technology } \\
\hline Present Value of Benefits* & $\$ 100,973$ & $\$ 97,042$ & $\$ 93,111$ & $\$ 89,179$ & $\$ 85,248$ \\
\hline Present Value of Costs* & $\$ 61,750$ & $\$ 61,750$ & $\$ 61,750$ & $\$ 61,750$ & $\$ 61,750$ \\
\hline Benefit- Cost Ratio & 1.64 & 1.57 & 1.51 & 1.44 & 1.38 \\
\hline Net Present Value* & $\$ 96,847$ & $\$ 87,141$ & $\$ 77,432$ & $\$ 67,726$ & $\$ 58,020$ \\
\hline NPV change over baseline* & $\$ 33,390$ & $\$ 31,642$ & $\$ 29,889$ & $\$ 28,138$ & $\$ 26,388$ \\
\hline Percent Change over Baseline & $52.62 \%$ & $57.01 \%$ & $62.87 \%$ & $71.08 \%$ & $83.43 \%$ \\
\hline
\end{tabular}

* At $5 \%$ rate of discount 


\subsubsection{Sensitivity to Change in the Level of Rainfall}

The base analysis assumed that the rainfall in the region averages around $233 \mathrm{~mm}$. Any change in the rainfall would affect irrigation requirements and thus cost to producer and the level of water use. For this sensitivity analysis, costs and benefits were evaluated under dry growing season (amount of rainfall $148 \mathrm{~mm}$ ) and wet growing season (amount of rainfall $355 \mathrm{~mm}$ ). Irrespective of the amount of summer rainfall, financially the BMP Technology outperformed the Baseline Technology. Difference between the two technologies (58\%) was noted for the dry summers, whereas during wet summers that gap decreases to almost 48\% (Table 6).

Table 6. Comparison of baseline and BMP system for cranberry production at different rainfall levels, $\$ \mathrm{ha}^{-1}$

\begin{tabular}{|c|c|c|c|}
\hline \multicolumn{4}{|l|}{ Baseline Technology } \\
\hline Particulars & Dry & Average & Wet \\
\hline Present Value of Benefits* & $\$ 214,309$ & $\$ 214,309$ & $\$ 214,795$ \\
\hline Present Value of Costs* & $\$ 153,395$ & $\$ 150,852$ & $\$ 60,066$ \\
\hline Benefit Cost Ratio & 1.40 & 1.42 & 1.44 \\
\hline Net Present Value* & $\$ 60,914$ & $\$ 63,457$ & $\$ 65,998$ \\
\hline \multicolumn{4}{|l|}{ BMP Technology } \\
\hline Present Value of Benefits* & $\$ 100,973$ & $\$ 100,973$ & $\$ 100,973$ \\
\hline Present Value of Costs* & $\$ 62,071$ & $\$ 61,750$ & $\$ 61,431$ \\
\hline Benefit Cost Ratio & 1.63 & 1.64 & 1.64 \\
\hline Net Present Value* & $\$ 96,054$ & $\$ 96,847$ & $\$ 97,635$ \\
\hline NPV change over Baseline & $57.69 \%$ & $52.62 \%$ & $47.94 \%$ \\
\hline
\end{tabular}

* At $5 \%$ rate of discount

\subsubsection{Change in Investment Cost}

Recent studies (e.g., [Pelletier et al., (2015)] have suggested common issues associated with poor drainage in cranberry fields. The cost of fixing these problems have also been reported by Jabet et al. (2016), which suggests that the initial cost of investment varies depending on the issue that requires correction. To ensure robustness of results, the NPV values for the BMP (Water-conserving) technology was estimated by assuming that the costs of investment increases by $10 \%, 15 \%$ and $20 \%$. Even under a $20 \%$ increase in the investment cost the BMP Technology remains economically viable and better than the Baseline Technology (Table 7).

Table 7. Comparison of baseline and BMP system at different capital investment costs for cranberry production $\left(\$ \mathrm{ha}^{-1}\right)$

\begin{tabular}{|c|c|c|c|c|c|}
\hline \multirow[t]{2}{*}{ Particulars } & \multirow[t]{2}{*}{ Baseline Technology } & \multicolumn{4}{|c|}{ BMP Technology } \\
\hline & & $0 \%$ & $10 \%$ & $15 \%$ & $20 \%$ \\
\hline Present Value of Benefits* & $\$ 214,307$ & $\$ 249,316$ & $\$ 249,316$ & $\$ 249,316$ & $\$ 249,316$ \\
\hline Present Value of Costs* & $\$ 150,852$ & $\$ 152,469$ & $\$ 153,197$ & $\$ 153,560$ & $\$ 153,926$ \\
\hline Benefit-Cost Ratio & 1.42 & 1.64 & 1.63 & 1.62 & 1.62 \\
\hline Net Present Value* & $\$ 63,455$ & $\$ 96,847$ & $\$ 96,119$ & $\$ 95,756$ & $\$ 95,390$ \\
\hline NPV increase over Baseline* & & $\$ 33,392$ & $\$ 32,664$ & $\$ 32,301$ & $\$ 31,935$ \\
\hline NPV increase over Baseline (\%) & & $52.62 \%$ & $51.47 \%$ & $50.90 \%$ & $50.33 \%$ \\
\hline
\end{tabular}

* At 5\% discount rate

\subsubsection{Change in Discount Rate}

Relative differences between the financial measures for the two technologies (Baseline vis-à-vis BMP) were estimated by using a discount rate of $5 \%$, and then increasing it to $10 \%$ and $15 \%$. Discounting future costs and benefits at higher rates increased the gap between NPVs for the two technologies slightly, with the BMP Technology still having higher net returns. At a discount rate of 5\%, the profitability of cranberry production under a BMP Technology, as estimated by NPV, is approximately 53\% higher than that under the Baseline Technology. At discount rates of $10 \%$ and $15 \%$, the increase over the Baseline Technology is $52.05 \%$ and $51.51 \%$ respectively (Table 8). 
Table 8. Comparison of baseline and BMP system for cranberry production at different discount rates $\left(\$ \mathrm{ha}^{-1}\right)$

\begin{tabular}{llll}
\hline Rate of discount & & & \\
\hline & $5 \%$ & $10 \%$ & $15 \%$ \\
\hline Present Value of Benefits & $\$ 214,309$ & $\$ 151,449$ & $\$ 115,563$ \\
Present Value of Costs & $\$ 150,852$ & $\$ 108,116$ & $\$ 83,686$ \\
Benefit Cost ratio & 1.42 & 1.40 & 1.38 \\
Net Present Value & $\$ 63,457$ & $\$ 43,333$ & $\$ 31,877$ \\
BMP Technology & & & \\
Present Value of Benefits & $\$ 249,316$ & $\$ 176,188$ & $\$ 134,440$ \\
Present Value of Costs & $\$ 152,469$ & $\$ 110,299$ & $\$ 56,143$ \\
Benefit Cost ratio & 1.64 & 1.60 & 1.56 \\
Net Present Value & $\$ 96,847$ & $\$ 65,889$ & $\$ 48,296$ \\
NPV change over Baseline & $52.62 \%$ & $52.05 \%$ & $51.51 \%$ \\
\hline
\end{tabular}

\section{Discussion}

Eastern Canada (particularly the province of Quebec) is an important producer of cranberries in the world. Effective water table management is considered a necessity for the region, particularly under the looming climate change threats that would affect water availability and producers' income. New methods of water table management have been developed, including the one where real time tensiometers were used to assess water needs, and subsurface drains are installed closer to one another (called BMP Technology). This technology is contrasted with the Baseline Technology being used by local cranberry producers -- growing cranberries under a relatively wet water management strategy, where the grower irrigated the crop twice every other day, without using a device to assess the water table level (called Baseline Technology). In both technologies, irrigation was done using sprinkler irrigation, together with a system of subsurface drains and control structures around cranberry beds. The main water source for irrigation purposes is an on-farm reservoir fed by rain or by water pumped from the Becancour River.

Using a BMP Technology based water management system for cranberry production was estimated to increase yields by $16 \%$ relative to the Baseline Technology, and a reduction in amount of water use. Irrigation costs under the BMP Technology were estimated to be lower as well. The study findings show that the Water-conserving BMP Technology increased net present value for the producer by $52.6 \%$. This was a result of changes in both revenues and production costs. Under this technology, present value of revenues increased by $16.3 \%$, while the present value of total cost only by $1.1 \%$ of the Baseline Technology. Although the benefit-cost ratios (BCR) for both technologies were greater than one, the BMP Technology consistently had higher BCR at 1.64.

The above findings were further scrutinized under alternative economic and non-economic conditions in the future. These included: cranberry yield and prices, change in future precipitation levels, cost of the project, and discount rates. Sensitivity analysis results indicated that irrigating cranberries using the BMP Technology was consistently more profitable than the Baseline Technology. Even with cranberry prices dropped by $20 \%$, the wet water management system still outperformed the water-conserving (baseline) system. Similar results were obtained for different discount rates (10\% and 15\%), at an increased cost of investment of up to $20 \%$, or if the producer faced higher cost. Even with an increase of $20 \%$ in the capital cost, the water-conserving technology resulted in over 50\% higher than the wet technology in present value terms.

While there is more certainty over the reliability of findings related to the financial feasibility of adopting these proposed BMPs, it is less clear what the environmental and social effects of these improved water management systems are. While data from secondary resources indicated that these alternative practices and technologies have the capacity to reduce water use, energy use, reduce GHG emissions and improve nutrient use efficiency, these findings have more uncertainty in the context of the studied farms. Furthermore, the technology is more complex and may require a higher quality of management.

\section{Conclusions}

Based on the financial analysis of cranberry production, it is concluded that the BMP Technology (use of real-time tensiometer based irrigation plan) offers higher economic returns to producers relative to the Baseline Technology (using irrigation based on evapotranspiration of the crop with no regard to the water table). On a per ha basis, the BMP Technology yields a net return of $\$ 98,847$, whereas the Baseline Technology produces 
$\$ 63,457$ - an increase of 52.6\%. Economic superiority of the BMP Technology is maintained under changes in various production variables, such as yield, crop price, initial investment cost, precipitation rates, and discount rates.

For those producers who are in search of high income yielding technologies, the BMP Technology offers a better alternative to irrigate cranberries than the Baseline Technology. Higher profits may also entice other producers to get into cranberry production and increase Canada's share of the world market. Increased production would definitely result in higher spin-off economic impacts (through forward and backward linkages) on the local and regional economies. However, a lack of adoption of the BMP Technology may be as a result of lack of knowledge of its economic superiority. Provision of this information could be an important step in the adoption process.

This can be used as a building block for future studies involving more complex stochastic models. In terms of contribution to direct application, even though broad generalization of results to the entire population of cranberry growers in Québec is not possible, this research provides transferable knowledge to other large farms in these regions, which have similar cultural practices and biophysical conditions.

\section{References}

Alston, J. M., Medellín-Azuara, J., \& Saitone, T. L. (2014). Economic Impact of the North American Cranberry Industry. Davis. University of California.

APCQ (Association des Producteurs de Canneberges du Québec). (2018). Profile of the Cranberry Industry. Retrieved from http://www.notrecanneberge.com/Content/Page/Profile

APCQ (Association des Producteurs de Canneberges du Québec. (2019). Culture de la canneberge au Québec (conventionelle and biologique). Retrieved from http://www.notrecanneberge.com/openfile.aspx?file=Statistiques-2018-culture-conv-bio.pdf

Averill, A., Caruso, F. L., DeMoranville, C. J., Jeranyama, P., LaFleur, J., McKenzie, K., Rinta, L., Sandler, H. A. \& Wick, B. (2008). Cranberry Production Guide. Paper 8. Retrieved from https://ag.umass.edu/sites/ag.umass.edu/files/pdf-doc-ppt/cranberry_production_guide.pdf

Caron, J., Pelletier, V., Kennedy, C. D., Gallichand, J., Gumiere, S., Bonin, S., Bland, W. L., \& Pepin, S. (2017). Guidelines of irrigation and drainage management strategies to enhance cranberry production and optimize water use in North America. Canadian Journal of Soil Science, 97(1), 82-91. https://doi.org/10.1139/CJSS-2016-0086

CRAAQ (Centre de Référence en Agriculture et Agroalimentaire du Québec). (2017). Canneberges - Budget 2017 (AGDEX 233/821). Retrieved from https://www.craaq.qc.ca/visionneuse/p/PREF0100/9aa97738-e2c1-4b8f-bcee-1dabcda6867a

Eilers, W., MacKay, R., Graham, L., \& Lefebvre, A. (Eds). (2010). Environmental Sustainability of Canadian Agriculture: Agri-Environmental Indicator Report Series - Report \#3. Agriculture and Agri-Food Canada. Ottawa, Ontario. p. 200.

Environics. (2006). National survey of farmers and ranchers: Ecological goods and services. Retrieved from http://www.whc.org/documents/EN5742landowners1.pdf

Jabet, T., Caron, J., \& Lambert, R. (2016). Payback Period in Cranberry Associated with a Wireless Irrigation Technology. Canadian journal of soil science, 97(1), 71-81. https://doi.org/10.1139/CJSS-2016-0011

MAPAQ (Ministère de l'Agriculture, des Pêcheries et de l'Alimentation du Québec). (2018). Portrait-diagnostic sectoriel de la canneberge au Québec. Retrieved from https://www.mapaq.gouv.qc.ca/fr/Publications/Portraitdiagnosticcanneberge.pdf

MacKay, R., Bennett, E. M., \& Lefebvre, A. (2010). Using a Beneficial Management Practice (BMP) Adoption Index. Agricultural and Agri-Food Canada, Ottawa, Canada. Retrieved from http://www.oecd.org/tad/sustainable-agriculture/44810471.pdf

Pelletier, V., Gallichand, J., \& Caron, J. (2013). Effect of Soil Water Potential Threshold for Irrigation on Cranberry Yield and Water Productivity. Transactions of the ASABE, 56(6), 1325-1332. https://doi.org/10.13031/trans.56.10374

Pelletier, V., Gallichand, J., Caron, J., Jutras, S., \& Marchand, S. (2015). Critical Irrigation Threshold and Cranberry Yield Components. Agricultural Water Management, 148, 106-112.

https://doi.org/10.1016/j.agwat.2014.09.025 
Pelletier, V., Gallichand, J., Gumiere, S., \& Caron, J. (2016). Impact of Drainage Problems on Cranberry Yields: Two Case Studies. Canadian Journal of Soil Science, 97(1), 1-4. https://doi.org/10.1139/cjss-2015-0132

Poirier, I. (2010). La Canneberge au Québec et au Centre-du-Québec: un Modèle de Développement Durable, à la Conquàte de Nouveaux Marchés. Ministère de l'Agriculture, des Pêcheries et de l'Alimentation du Québec. Retrieved from https://www.mapaq.gouv.qc.ca/fr/Publications/LaCannebergeauQuebec.pdf

Roper, T. R. (2008). Cranberry Production in Wisconsin. Retrieved from http://www.wiscran.org/user_image/pdf_files/CranProduction08.pdf

Roper, T. R., \& Vorsa, N. (1997). Cranberry: botany and horticulture. Horticultural reviews (USA). https://doi.org/10.1002/9780470650660.ch7

Sandler, H., \& DeMoranville, C. (2008). Cranberry Production: A Guide for Massachusetts - Summary Edition. Cranberry Production Guide 1. Retrieved from https://scholarworks.umass.edu/cranberry_prod_guide/1

Sandler, H. A., DeMoranville, C. J., \& Lampinen, B. (2004). Cranberry Irrigation Management. Cranberry Station Fact Sheets, 12. Retrieved from https://scholarworks.umass.edu/cranberry_factsheets/12

Statistics Canada. (2011). Socio-economic Indicators for Tomato, Cranberries and Onion Farms, Census of Agriculture, 2011. Ottawa, ON.

Statistics Canada. (2019c). Table: 32-10-0364-01 (formerly CANSIM 001-0009) Estimates, production and farm gate value of fresh and processed fruits $(x 1,000)$. Retrieved from https://www150.statcan.gc.ca/t1/tbl1/en/tv.action?pid=3210036401\&pickMembers\%5B0\%5D=1.8\&pickM embers $\% 5 \mathrm{~B} 1 \% 5 \mathrm{D}=2.2 \&$ pickMembers $\% 5 \mathrm{~B} 2 \% 5 \mathrm{D}=4.5$

\section{Copyrights}

Copyright for this article is retained by the author(s), with first publication rights granted to the journal.

This is an open-access article distributed under the terms and conditions of the Creative Commons Attribution license (http://creativecommons.org/licenses/by/3.0/). 